\title{
Meaningful Learning Experiences in Learning Islamic Science and Technolgy Via Online Method
}

Noraishah P Othman, Mahfuzah Mohammed Zabidi, Ahmad Rozaini Ali Hasan, Iza Faradiba Mohamad Patel

To Link this Article: http://dx.doi.org/10.6007/IJARBSS/v12-i1/11271

DOI:10.6007/IJARBSS/v12-i1/11271

Received: 17 November 2021, Revised: 20 December 2021, Accepted: 09 January 2022

Published Online: 27 January 2022

In-Text Citation: (Othman et al., 2022)

To Cite this Article: Othman, N. P., Zabidi, M. M., Hasan, A. R. A., \& Patel, I. F. M. (2022). Meaningful Learning Experiences in Learning Islamic Science and Technolgy Via Online Method. International Journal of Academic Research in Business and Social Sciences, 12(1), 2523-2536.

Copyright: @ 2022 The Author(s)

Published by Human Resource Management Academic Research Society (www.hrmars.com)

This article is published under the Creative Commons Attribution (CC BY 4.0) license. Anyone may reproduce, distribute, translate and create derivative works of this article (for both commercial and non0-commercial purposes), subject to full attribution to the original publication and authors. The full terms of this license may be seen at: http://creativecommons.org/licences/by/4.0/legalcode

Vol. 12, No. 1, 2022, Pg. $2523-2536$

Full Terms \& Conditions of access and use can be found at http://hrmars.com/index.php/pages/detail/publication-ethics 


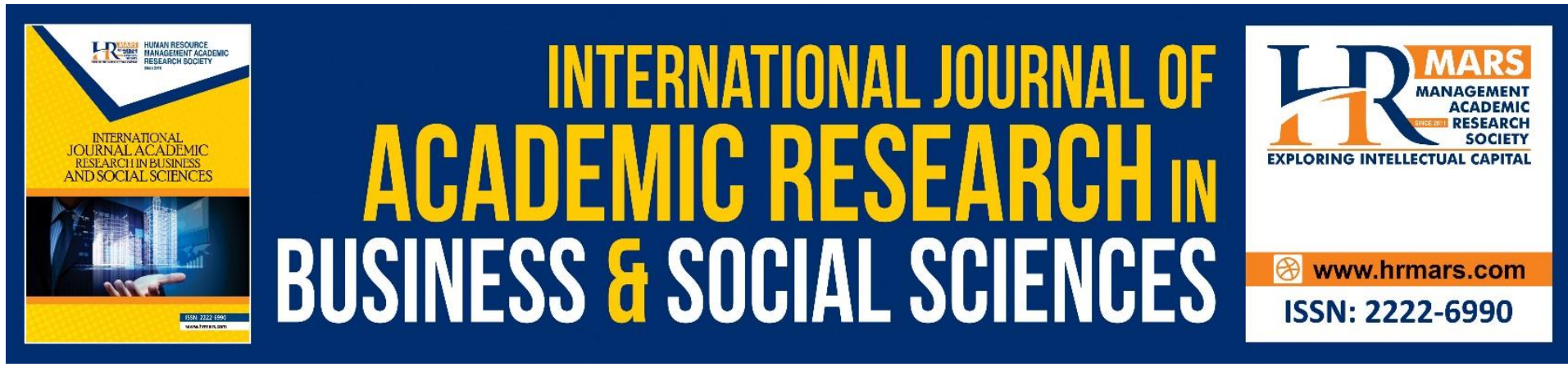

\title{
Meaningful Learning Experiences in Learning Islamic Science and Technolgy Via Online Method
}

\author{
Noraishah P Othman ${ }^{1}$, Mahfuzah Mohammed Zabidi², Ahmad \\ Rozaini Ali Hasan ${ }^{3}$, Iza Faradiba Mohamad Patel ${ }^{4}$ \\ ${ }^{1,2}$ Academy of Contemporary Islamic Studies Universiti Teknologi MARA Johor Branch Pasir \\ Gudang Campus, ${ }^{3}$ Academy of Contemporary Islamic Studies Universiti Teknologi MARA
} Perak Branch Seri Iskandar Campus, ${ }^{4}$ Academy of Language Universiti Teknologi MARA Perak Branch Seri Iskandar Campus

\begin{abstract}
Islamic Science and Technology course that is offered at the tertiary level aims to expose learners about the basic concept of Islamic philosophy with the outcome of learners being able to reflect good moral values regardless of the fields being undertaken. Due to the pandemic, this course must be conducted online. Due to the change of mode of delivery, lecturers are still required to ensure learners are still able to gain meaning learning experience. The objective of this article is to study the perception of learners towards factors contributing to meaningful learning experience of the course. Respondents include 121 Diploma level students from a selected higher learning institution. Data was analyzed using ATLAS-ti 8, a qualitative research software. Results are presented using "The Formation of Meaningful Learning Experiences Model" which consists of four main elements mainly lecturer, learning environment, structured teaching, and connectedness.
\end{abstract}

Keywords: Meaningful Learning Experiences, Islamic Science, Islamic Education, Teaching

\section{Introduction}

There is a drastic shift in the mode of teaching due to the Covid 19 pandemic which erupted in March 2020. This shift has indirectly opened room of opportunities for Malaysian education culture to be at par with the demands of the global world and the Industrial Revolution 4.0. Hence, the two common online learning methods are synchronous and asynchronous learning. Also, the teaching and learning needs to be strategized and a detailed and thorough preparation is required to ensure the objective of meaningful learning experiences are achieved.

The Islamic Science and Technology course is one of the required courses to be fulfilled by students of Diploma in Science and Technology. The main objective of this course is the application of the fundamentals of Islamic Sciences-the principal core to the knowledge of science and technology; the reflection of good moral values among the learners in all the fields undertaking. This is aligned with the values outline in the al- Quran and al-Sunnah; competitiveness in evaluating and in decision-making based on principles of maqasid syariah dan qawaid feqah (Hisyam, 2018). 
The course provides learners with the basics of integrating Islamic principles in the field of science and technology. In addition, it assists learners in identifying and associating current issues with the basis in law enforcement through the exposure in maqasid Syariah as well as qawaid fiqhiyyah. Therefore, it is essential to ensure learners can gain as many benefits as possible through the application of Islamic knowledge and integration of science and technology in this course Thus, it is through meaningful learning experiences the above objectives can be achieved.

\section{Meaningful Learning Experiences}

The concept of meaningful learning was derived from the constructivist theory where learners need to develop his or her own knowledge independently. Likewise, the ability to develop new knowledge and understanding is obtained through reflections of one's self-experiences or others (Mayer, 2002; Howland et al., 2012t). Besides reflecting, the active cognitive process can further be stimulated through exploring, collaborating new and relevant resources and discussions until a new and genuine understanding of the knowledge is achieved (Jonassen et al., 2003).

Meaningful learning involves five learning dimensions namely cooperative, active, authentic -emphasizes on individual diversity, constructive and directed (Howland et al., 2012). These five dimensions involves (i) learner - lecturer, and learner - peer interaction (ii) learner readiness to actively involved in the learning process and to explore new information throughout the learning process (iii) learner ability to relate the content with daily experiences and real-life situations and simultaneously, identify solutions to the problems of the society. (iv) developing new understanding through the application of prior and new knowledge, and (v) reflecting on the learning process (Howland et al., 2012).

All the five meaningful learning dimensions depict several main characteristics that need to be present in every teaching and learning process namely: (i) active cognitive process (ii) active and comprehensive participation (iii) recognizing individual diversity and (iv) reflection. Lecturers can encourage the process by stimulating learners' inquisitiveness, encouraging collaborations, involving learners in the process of organizing ideas (individually or in groups), developing the knowledge, and requiring the learners to reflect in the completed activity (Ghazali \& Nordin, 2019). The process of developing meaningful learning experience considers learners' existing or prior knowledge, aptitude, inclination, interest and learning style. All of these contribute meaningfully to their learning experiences (Nazuar \& Aida, 2018; Malini \& Abdul Malek, 2020).

Despite the emphasis of constructivism theory is on learners developing their own meaningful knowledge, lecturers do play a significant role of an agent to provide a conducive learning environment that can stimulate learners' motivation and interest to pursue the learning. The teaching must be oriented on mastery of the learned subject with emphasis on learners' effort and ability to continuously improving themselves and understanding of knowledge which is relevant to them and their lives (Sonmez et al., 2018). Therefore, three factors have been identified to encourage learners' motivation to obtain meaningful learning experiences. They are (i)lecturer (ii) learning environment and (iii) structured teaching (Anderman \& Wolters, 2006). 


\section{i) Lecturer}

A lecturer handles the teaching and learning session. He or she is responsible to prepare a meaningful learning experience for the learners, is confident that each learner's ability can be enhanced, is responsible to set realistic learning objectives and is focused on learners' improvement. Therefore, he needs to develop a positive relationship with his students so that they can convey ideas comfortably and are more accepting and ready to face criticisms from both the lecturer and their colleagues critically and positively. (Sonmez et al., 2018).

Moreover, a lecturer needs to display his passion and interest on the topic that is being taught. This is because, a passionate lecturer creates a better and more positive learning environment (Rico \& Ertmer, 2015). Learners' motivation to strive for meaningful learning experiences can be achieved with the lecturer's effort to (i) create a more positive lecturerlearner relationship (ii) create deep interest in learning through concrete evidence (iii) encourage active participation in learning activity (iv) emphasize understanding dan the process rather than grades and achievement ( $v$ ) encourage collaboration instead of competition (Anderman \& Wolters, 2006; Sailin \& Mahmor, 2017).

\section{ii) Learning Environment}

A safe and organized learning environment motivates learning as there is need for learners to feel emotionally secured. Positive learning environment makes learners feel accepted and this simultaneously prevent them from wasting their time thinking about ways to avoid criticisms, threat and being ridiculed. It also encourages collaborations, expressions of view and ideas, as well as promotes learners to get involve completely in the learning process. (Emmer \& Evertson, 2013; Sailin \& Mahmor, 2018).

A conducive learning environment includes lecturers' commitment to assign challenging tasks to the learners. They also give clear instructions and feedbacks throughout the learning process. Learners are given opportunities to engage in discussions during the pre, and post presentation sessions or during sharing session of learners' assignments. Evaluation of assignments must be made based on quality of work, creativity, originality, contribution in group and presentation. Realistic challenges in learning not only increase motivation but also promotes creativity among the learners. (Rico \& Ertmer, 2015; Norliza et al., 2020).

Learning environment that integrates the use of technology also has a positive impact on learners. This enables them to present their assignments in various techniques that will indirectly stimulates their creativity, for example, video making, infographic, etc (Malini \& Abdul Malek, 2020). This exercise promotes freedom expression of views and creativity, exploration, generating new form of thinking, relating learning resources with the learners' real-life experiences. Finally, the outcome that needs to be achieved is the mastery of fundamental knowledge so that the values obtained from it can be appreciated and utilised completely (Esteban et al., 2017; Ghazali \& Nordin, 2018).

\section{iii) Structured teaching}

Structured teaching prepares learners to be mentally and physical ready to go through the learning process in a structured and organized manner. In this case, lecturers are responsible to plan a learning experience that can stimulate -self-regulated learning. Thus, structured teaching motivates learners to participate actively, so that and this drives them to discover their own learning style and strategy (Nazuar \& Aida, 2018). 
The strategy to motivate learners begins with the effort to attract their attention during the set induction phase. Here, the lecturer can present the problem, provide concrete examples, or state the learning objective and share the rationale of the topic that is going to be learned. In the development phase, lecturers need to relate the topic of the day with learners' reallife experience so that learners can relate to the relevance and authenticity of the lessons so that they are able to practise the knowledge and experience in their daily lives (Halyer, 2015; Malini \& Abdul Malek, 2020). Lecturers can both support and enhance the learning process through providing individual feedbacks, designing a clear and focused course document, driving meaningful online discussions, designing articulate course outcome and objectives, providing feedbacks and advise in an appropriate timeline. (Andrew, 2007; Emmer \& Evertson, 2013).

In an online learning mode, lecturers need to play an active role to ensure all the factors in the model are created so that learner interest and attention can be retained. Since online learning may create issues related to i) time constraints ii) short attention span ii) restlessness and handling the overwhelming number of sources from the internet and iv) online and technology literacy, lecturers need to find ways to ensure learners' motivation is at the optimal level so that the intended learning outcome can be achieved (Ghazali \& Nordin, 2018; Norliza et al., 2020).

\section{Research Methodology}

This qualitative research employs a case study method to capture a holistic view of the Islamic Science and Technology learners' reflection towards the course. Respondents include 121 diploma students in the Science and Technology cluster. The research was conducted at the end of the semester so that their feedbacks and reflections about their online teaching and learning experience can be obtained. All the data were uploaded in the Atlas-ti8 software and were analysed thematically. The objective of developing the research theme is to identify the thematic pattern in online learning. This will help to explain the issue being researched comprehensively and descriptively. All the data obtained have been screened through a verification technique namely member checking and peer debriefing which involved two lecturers teaching the same course.

\section{Research Findings}

This research involved respondents among diploma level students. A total of 68 students which comprised 68 males and 53 females. As for the academic term, majority of the respondents (97) were semester 4 , followed by 24 students from semester 3 respectively. The main learning platform utilised in this research was Microsoft Teams.

Three main themes related to meaningful learning experience were derived from this research. Figure 1 generally describes the themes in this research.

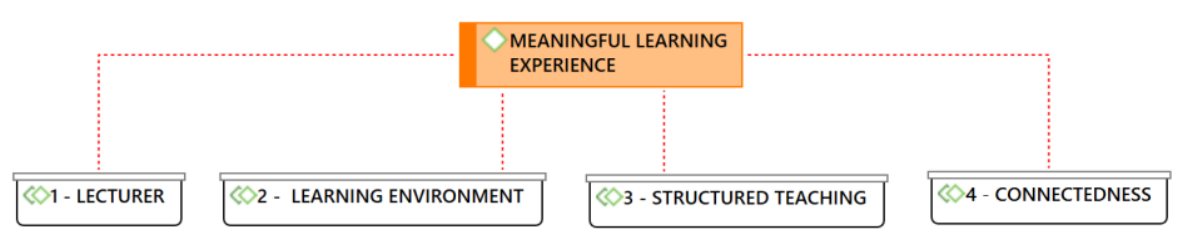

Figure 1: Emerging themes under Meaningful Learning Experience 
Figure 1 explains the breakdown of the overall subthemes from the three main themes that will be discussed in this article. The first theme which is lecturer consists of three subthemes which are positive empathy, and communication. Secondly, learning environment consists of three subthemes too which are safety, technology and challenging tasks. The third theme which is structured teaching consists of six subthemes which are recently developed skills, reflections, teaching resources and self-regulated learning, learners' motivation, and group activity. A new theme emerged from this research known as connectedness which will be discussed in the following subtopic.

\section{Learners' Perceptions towards Lecturer Factor}

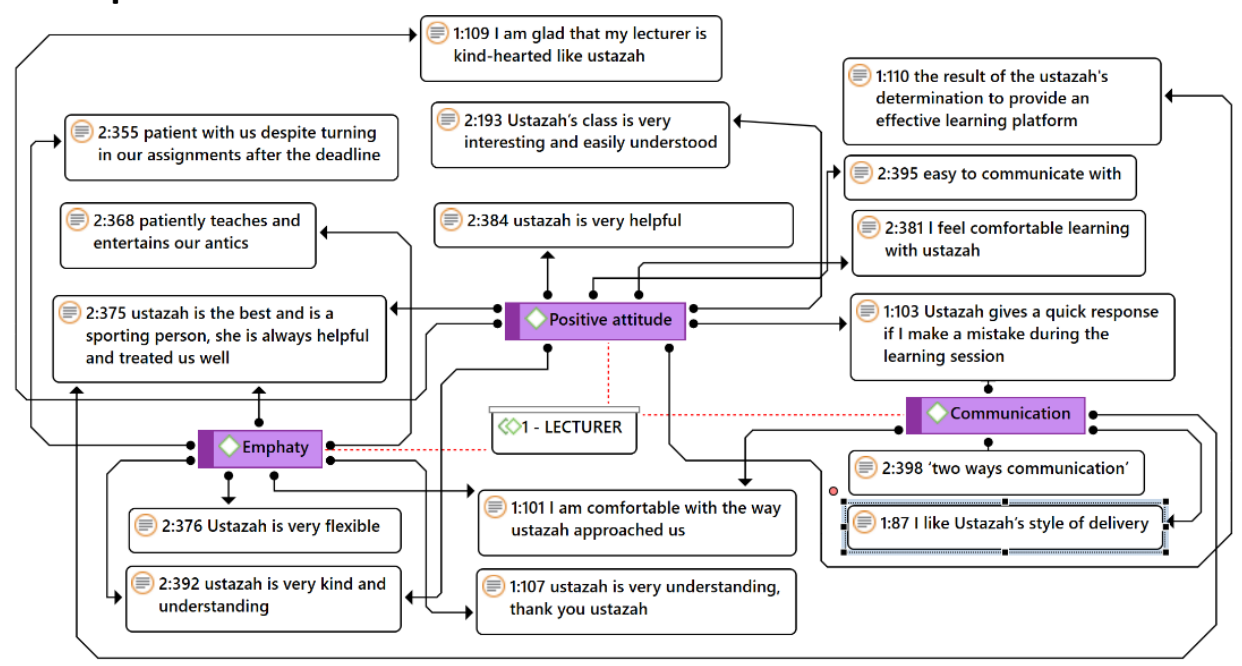

Figure 2: Learners' Perceptions towards Lecturer Factor

Figure 2 displays findings related to the first theme- lecturer factor that comprises three subthemes of empathy, positive attitude, and communication. It is found that empathy becomes the most important element to establish positive relationship between the lecturer and the learners. Some examples of empathy stated by the learners are patience and tolerance; "Ustazah is very flexible (2:376, August 2020)", patiently teaches and entertains our antics (2:368 August 2020)", "patient with us despite turning in our assignments after the deadline (2: 355, August 2020)".

Positive relationship which is the second subtheme describes a warm and friendly relationship between the lecturer and the learner. Both parties are comfortable in playing their role to ensure the success of the teaching and learning process. Some of the recorded feedbacks, are "ustazah has been extremely helpful" (2: 384 August 2020), "easy to communicate with" (2: 395, August 2021) and "I feel comfortable learning with ustazah" (2: 381, August 2021), "I am glad that my lecturer is kind-hearted like ustazah" (1: 109 August 2020).

Finally, is the third subtheme which is communication. It is found that the lecturer and the learners practised an open and effective form of communication. Students expressed a sense of comfort and understanding with the approach implemented by the lecturer, namely, "I am comfortable with the way ustazah approached us" (1: 101 August 2020), "ustazah is the best and is a sporting person, she is always helpful and entertain us in a kind manner" (2: 375 August 2020) ), "Ustazah gives a quick response if I make a mistake during the learning session" (1: 103 August 2020). 
From these findings, it can be understood that a positive teacher attitude, empathy, and the ability to communicate well can create a learning environment that can help learners gain a meaningful learning experience.

\section{Learners' Perception towards Learning Environment Factors}
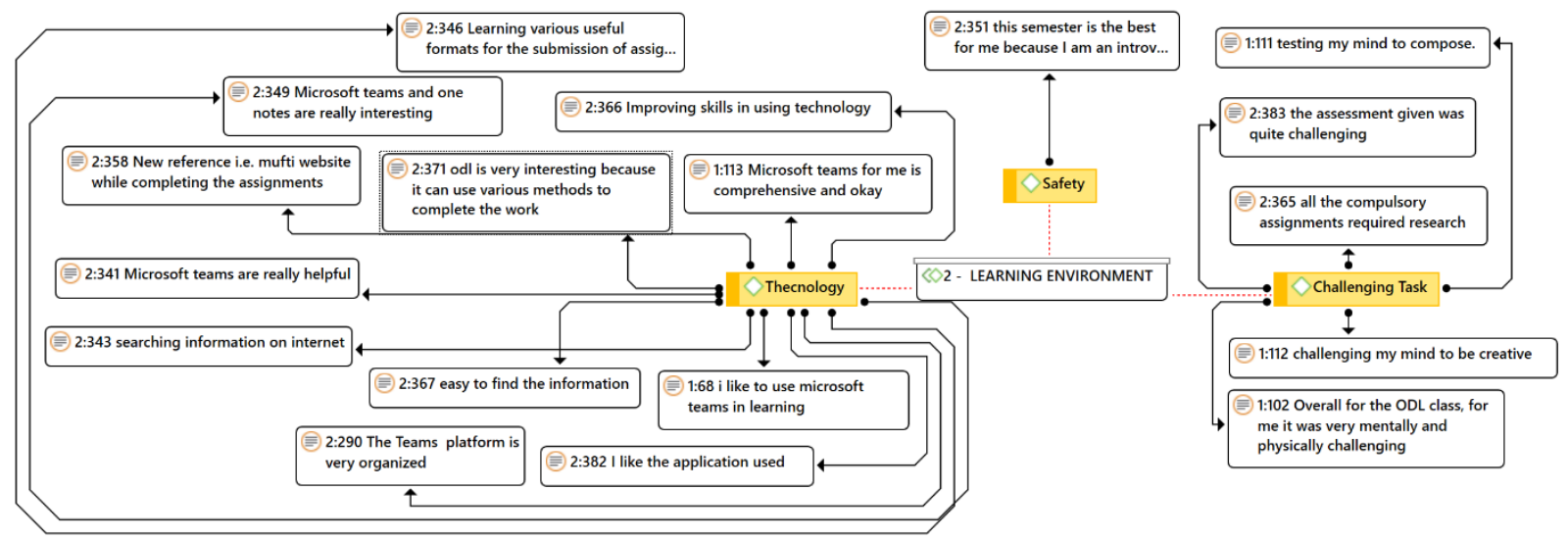

Figure 3: Learners' Perceptions towards the Learning Environment

Figure 3 describes the second theme which is learners' perceptions towards the learning environment. There are three subthemes namely, technology, safety, and challenging tasks. All the elements mentioned play an important role in ensuring a meaningful learning experience among the learners. It is noted that technology is one of the main subthemes that is often repeated by learners. Most respondents expressed satisfaction, ease, and comfort with the use of Microsoft Teams platform and One Notes application. In addition, they also expressed their satisfaction with the teaching method used by the lecturers through videos and slides prepared for each topic. In addition, learners stated that they learned and explored the use of various new applications and sought additional information throughout the teaching and learning sessions. Students stated, "The Teams platform is very organized" (2: 290 August 2020), "Microsoft teams and one notes are really interesting" (2: 349 August 2020), "Improving skills in using technology" (2: 366 August 2020), "Microsoft teams for me is comprehensive and okay "(1: 113 August 2020)," Learning various useful formats for the submission of assignments "(2: 346 August 2020)," New reference i.e. mufti website while completing the assignments" (2: 358 August 2020).

The second subtheme, namely challenging tasks, shows that the learning environment also includes aspects of critical and creative thinking. The results of the study reported that learners also acknowledged the existence of an element of challenge in the teaching and learning process. Among the assignments given by the lecturers to the students are case studies related to current issues in science and technology and their relationship with Islam and law enforcement training based on the principles of maqasid syariah and qawaid fiqhiyyah for contemporary issues in science and technology. Their responses were as follows, "challenging my mind to be creative" (1: 112 August 2020), "the assessment given was quite challenging" (2: 383 August 2020), "all the compulsory assignments required research" (2: 365 August 2020)

Meanwhile for the third subtheme it is safe to show that learners revealed that "this semester is the best for me because I am an introvert" (2: 351 August 2020). Although average learners stated they were more likely to go through face-to-face learning process, but the findings of the study showed that online learning is preferred by introvert learners. They feel 
safe, comfortable to be actively involved in the teaching and learning sessions throughout the semester.

\section{Structured Teaching}

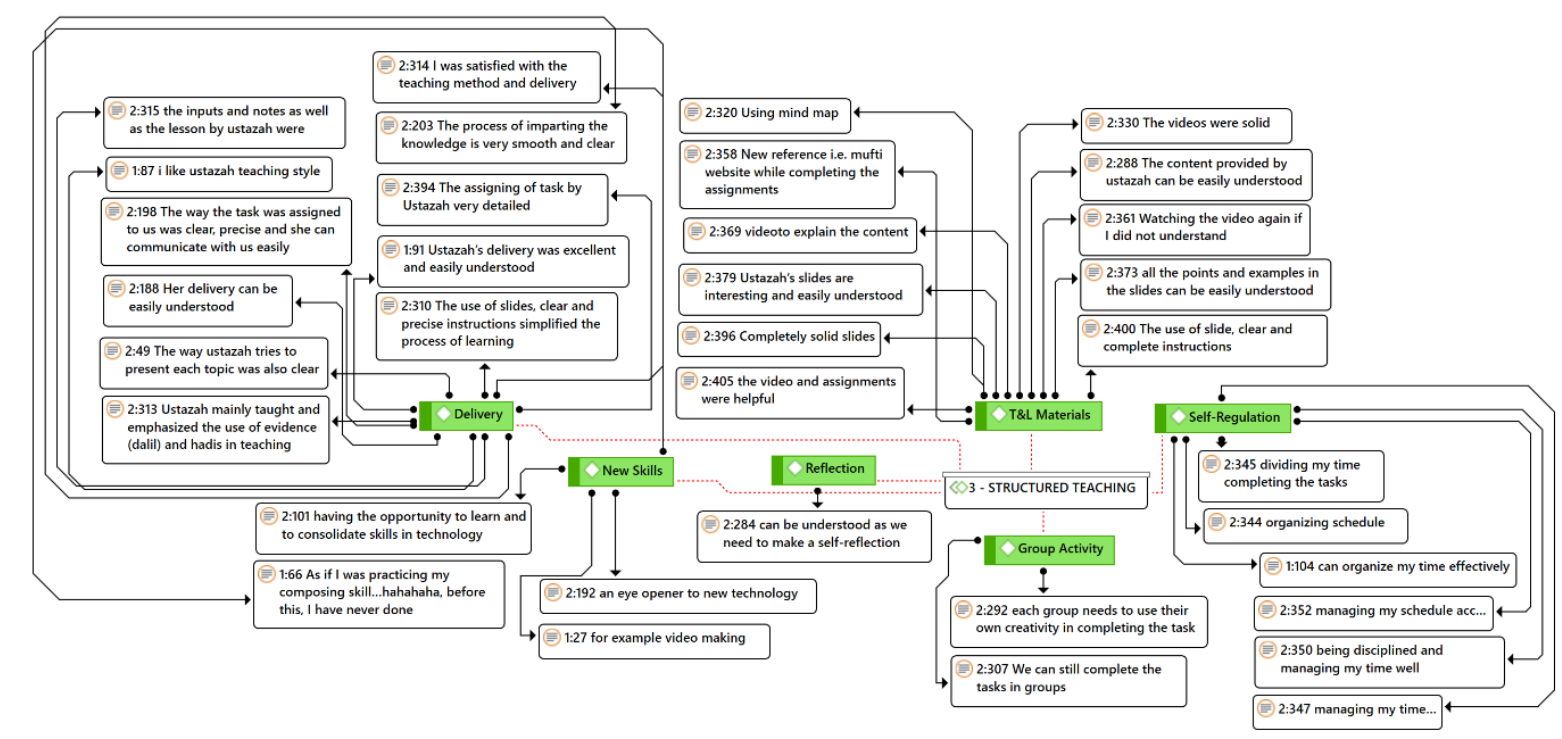

Figure 4: Learners Perceptions Towards Structured Teaching

The next theme is structured teaching which covers six subthemes namely teaching and learning materials, self-regulated learning, motivation and new skills, presentation, group activities and reflection. For the first subtheme which is teaching and learning materials showed that majority of the learners were satisfied with the materials provided by the lecturers. They used videos, slides and additional websites in the teaching and learning process. The use of online platforms as well as teaching materials adds value to the learning sessions as learners can do revision by repeatedly watching the teaching videos.

Among the findings stated are as follows: "ustazah's videos were solid" (2: 330 August 2020), "watching the video again if I did not understand" (2: 361 August 2020), "Ustazah's slides were interesting and easy to understand" (2:379 August 2020), "the contents that the ustazah shared were very easy to comprehend" (2: 288 August 2020), "new references such as the mufti's website while doing the assignments" (2: 358 August 2020).

The second subtheme is self-regulation. It is an important element that must be present in a learner to obtain optimal output in all teaching and learning sessions. Among the elements of self -regulation are the ability of students to manage their time and learning schedule effectively and to stay motivated and optimistic. The results of the study reported that despite the sudden changes in learning methods, most learners could manage their time well. They stated that the "can schedule our time well" (1: 104 Aug 2020), "can divide the time to complete the tasks" (2: 345 August 2020), "Organize schedules accurately" (2: 352 August 2020), "manage time more carefully" (2: 347 August 2020).

The delivery subtheme is one of the important components to achieve under structured teaching and learning. A good teaching structure gives more impact to the meaningful learning experience of the learner. In this subtheme, it is very important to have a clear and orderly lecturer to students' communication. The results of the study reported as follows, "the task assigned by ustazah was very detailed and she was easy to communicate with" (2: 198 August 2020), "Ustazah tried to present each topic clearly" (2:49 August 2020), 
"Ustazah's delivery can be understood clearly" (2: 188 August 2020), "the use of clear, concise slides and instructions further simplifies matters" (2: 310 August 2020).

Meanwhile, for the subtheme of group activities, it was reported that learners felt happy to still be able to carry out group learning activities even though they were implemented online. Meanwhile, for the subtheme of learners' reflection, the lecturer's approach of asking them to reflect at the end of each lecture session is commendable because it facilitates and gives more impact to learners' understanding. However, it is very important for lecturers to train and guide learners to produce effective reflection in each teaching and learning session.

\section{Learners' Perceptions towards Connectedness}

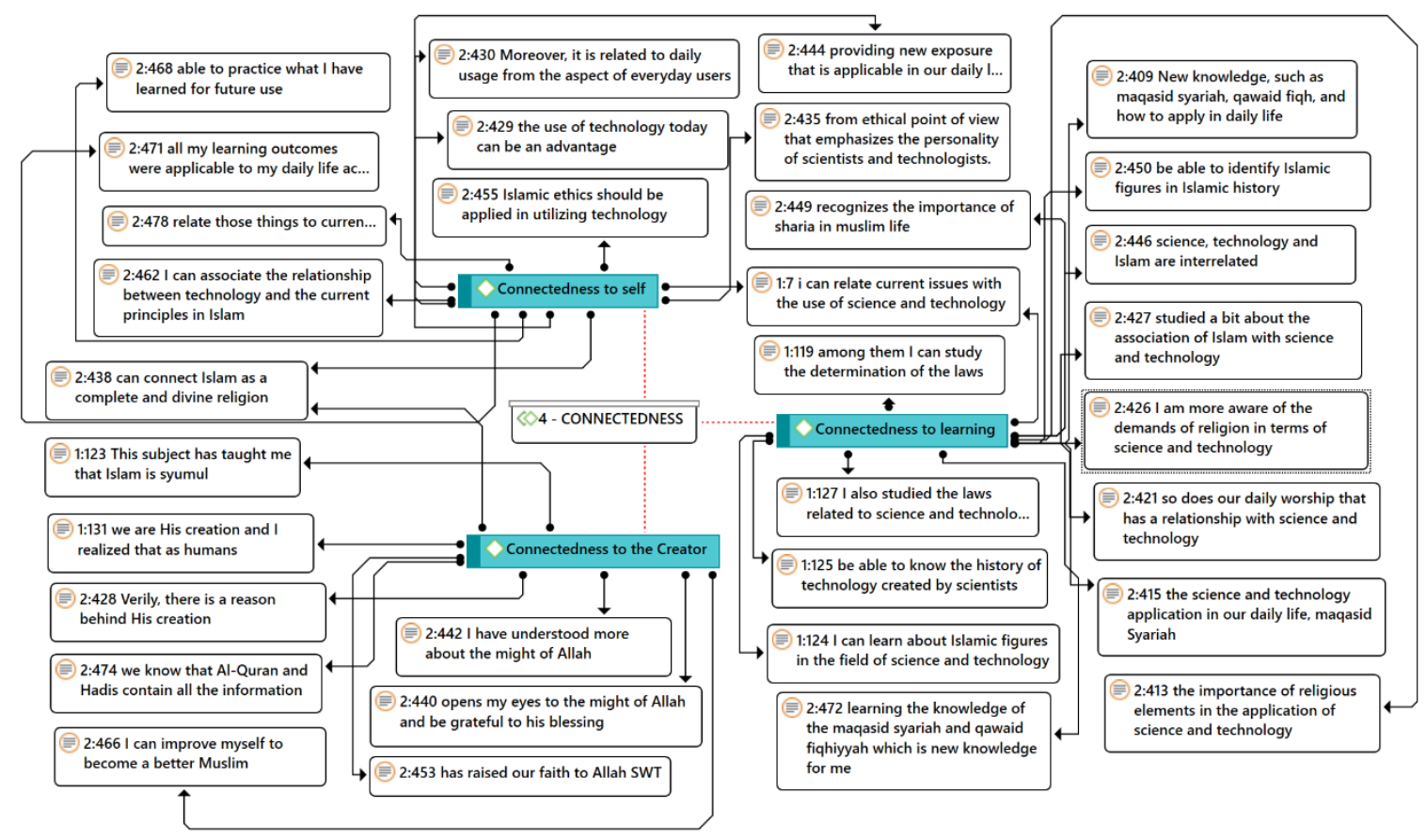

Theme 4: Connectedness

The fourth theme is a new emerging theme that is the aspect of connectedness. It is an important element in creating meaningful learning. There are three subthemes of connectedness, namely connectedness to the Creator, connectedness to learning and connectedness to self.

Connectedness with the Creator is a very important element that needs to be applied in the teaching and learning sessions to nurture learners' faith in Allah SWT. In fact, every field of learning requires the integration of these elements to strike a more balanced and harmonious construction of learners' spiritual and physical development. The results of the study reported that among the learners' comments were, "opened my eyes to admire and to be grateful to the mighty of Allah" (2: 440 August 2020), "This subject has taught me that Islam is actually syumul" (1: 123 August 2020), "increase our faith in Allah SWT"(2: 453 August 2020), "I can improve myself to become a pious Muslim "(2: 466 August, 2020).

The second subtheme is connectedness to learning. The results showed that learners have a deep connection with the subject studied. This is evident in the learning outcomes where it has helped learners to better understand and appreciate the true concept of Islamic science. Learners were also found to be able to relate Islamic elements to the field they were involved in. Among the responses were, "I also learned about the laws related to science and 
technology" (1: 127, August 2020), "science and technology are very closely related to Islam" (2: 446, August 2020), "able to identify prominent Islamic figures in the history of science "(2: 450, August 2020), " acquiring new knowledge such as maqasid syariah, qawaid fiqhiyyah and how they are applied "(2: 409, August 2020)," the importance of religious elements in the application of science and technology "(2: 413 Aug, 2020)

The third subtheme obtained from this study is connectedness to self. It explains that the teaching and learning that takes place throughout the semester has an impact in the personal development of the students which in turn created a more balanced thinking and behaviour which aligns with the principles of Islam. They were also able to evaluate the knowledge gained and make appropriate decisions in line with the demands outline in the religion. Among the learners' responses were, "I can relate the current issues and the use of science and technology ..." (1: 7 August 2020), "all learning outcomes were applicable for daily life" (2: 471 August 2020), "able to practice what I have learned later in the future" (2: 468 August 2020), "can relate these things to the current issues today" (2: 478 August 2020).

\section{Discussion}

It can be concluded from the findings that there are both internal and external factor that contribute to meaningful learning experience. Internal factor includes learners themselves while external factors include lecturers, the learning environment and structured environment as well as connectedness.

From a constructivist point of view, the process of turning conventional learning into meaningful learning experience depends on the effort and the commitment of the learners themselves. They need to go through active cognitive process, total participation in the learning activity, fearless enough to express opinions and one's unique quality, reflective enough to relate the newly obtained knowledge and experience with their current existing knowledge (Ausubel et al., 1978; Esteban et al., 2017; Malini \& Abdul Malek, 2020).

The lecturer who is handling the teaching and learning process needs to practise positive communication, display an open, friendly, and approachable attitude towards all his or her learners. Being empathetic promotes positive relationship with the learners and this helps to stimulate interest and inquisitiveness as well as active and complete participation in the learning process. Despite the lack of physical interaction between the lecturers and the learners due to the limitations of online learning mode, the human touch element can still be realized with lecturers' own initiative and creativity. The learners - lecturer relationship relies on how the lecturer views his or her role towards the learners. He can initiate a two-way communication with the learners using the most accessible platform so that all the announcements, instructions, tasks, and assignments can be conveyed effectively to all the learners. Hence, learners' enquiries can be addressed efficiently and effectively (Sonmez et al., 2018; Azhar, 2017; Ghazali \& Nordin, 2018).

Although the lecturer plays the role as a facilitator to facilitate the process of teaching and learning, he is also responsible to plan a structured teaching so that learners can gain optimum intended results out of the learning outcome. Structured teaching begins with the lecturer outlining a clear learning objective, providing clear instructions of activities that stimulates cognitive, collaboration and reflection among the learners. Structured teaching also helps learners to master the fundamentals required in a topic being covered. Learners are also given the freedom to select the topic and the presentation mode for the assignment (Howland et al., 2012; Rico \& Ertmer, 2015). 
Besides having a safe environment for learners to share ideas and views, they also need challenging tasks and assignments. Challenging tasks do not mean the quantity but instead a task that stimulate learners' inquisitiveness and can be completed within the stipulated time given and within learners' capacity. A safe environment also facilitates learners to engage in discussions with the lecturer during the different phases (before, during and after) completing the assignment. (Anderman \& Wolters, 2006; Sailin \& Mahmor, 2018).

The stated factors shape students' positive beliefs on aspects such as expectations, mindset, attributions and self-efficacy towards their own learning. Indirectly, students get intrinsic motivation that focuses on their understanding and appreciation of the knowledge learned, where the learning experience integrated a sense of challenge and autonomy, arouse curiosity, and celebrate creativity and imagination. Consequently, these learning features help increase students' intrinsic motivation to continue exploring and deepening the knowledge learned even after graduation (Eggen \& Kauchak, 2016).

From the Islamic perspective, meaningfulness that is hoped to achieve in any learning activities does not only revolve around new knowledge emerging from the existing knowledge but most importantly is the connectedness with the Creator Allah SWT in all the knowledge aspects being learned. It is outlined in the objective of Islamic Education that learners need to recognize Allah SWT and acknowledge. His divinity by doing good according to His law (Bakar, 2016; Nor, 2019).

The enjoyment that is obtained during the process of meaningful learning experience is not meaningful until one has obtained enlightenment to the truth which leads him to deeper appreciation that affects his daily behaviour and practice as a human being. Therefore, meaningful learning from the Islamic point of view involves the construction of an accurate view of nature, feelings or emotions based on kindness (ihsan) and a set of behaviour appropriate to the role and responsibilities as a servant and caliph (Yusuf, 2020; Bakar 2016). Likewise, the lecturer should plan the teaching and experience of learners that can reflect the nature and the name of Allah SWT in the knowledge being learned. With that, students can integrate the science learned with the concept of Tawhid. The deeper the knowledge learned, the broader the awareness of the Existence and the Might of Allah

In addition, the connection with lesson content can be achieved through reflection. This process of reflection will only be beneficial when the student has the right frame of mind according to the Qur'an and the Sunnah. Without this framework, students are prone to confusion and misunderstanding especially in dealing with the overwhelming amount of information on the internet. The lecturer's guidance. throughout the completion process of the assignments, the discussion sessions guide the learners in sharing their ideas so as not to deviate from the framework of Islamic thought. In the CTU211 course, what is expected in the process of reflection is that students acquire a positive self -formation, achieve self -meaning as a servant and caliph of God to spread prosperity to all people. (Rico \& Ertmer, 2015; Nor 2019).

\section{Conclusion}

Meaningful learning is crucial to aid the process of appreciating the learned knowledge in class so that it can be applied in real life situations. There are four main elements of meaningful learning which are active thinking process, overall commitment in the learning activities, recognizing learners' individual differences or diversity and reflective process. These four elements are driven by another four significant factors which are lecturers, learning environment, structured teaching, and connectedness. From the Islamic 
perspective, meaningful learning experience needs to be associated with the existence of the Almighty in the knowledge framework of fundamentals Fard' Ain (akidah, syariat and akhlak). Thus, a new model has been derived from this research; "The Development of Meaningful Learning Experience Model" which includes four main themes - lecturer, learning environment, structured teaching, and connectedness.

Theoretically, this study develops a meaningful learning model that previously focused on lecturer factors, learning environment and structured teaching only. It has successfully incorporated connectedness factors to obtain meaningful learning. Without the aspect of "meaningfulness" in meaningful learning experiences, students will find it difficult to remember what they have learned but also find it difficult to practise the knowledge and values learned in real-life (meaningful) situations. The connectedness factor also provides internal motivation for students to continue exploring knowledge and constructing new knowledge and insights in the field being studied. In addition, this study highlights the importance of the aspect of knowledge connection with self, and the relationship of self (one who seeks the knowledge) with the Creator (divine aspect) as Allah SWT is the main source of knowledge and truth.

In practical terms, educators are not only required to be friendly and caring to students and ensure a safe and challenging learning environment, but also need to design teaching sessions to achieve a level of "meaningfulness" that touches the minds and hearts of the students. Consequently, the connectedness factor drives lecturers to meticulously plan the delivery of content, learning activities and assignments to be assigned to the students so that they are able to apply and utilize the knowledge in real life. Meaningful learning supported by all the discussed elements help to consolidate and reinforce learners' sense of purpose as a khalifah or a servant of Allah where the sole purpose is to spread kindness and to ensure universal well-being is preserved through integrated Islamic science knowledge.

\section{References}

Anderman, E. M., \& Wolters, C. A. (2006), Goals, values and affect: Influences on motivation. In P.A Alaxender \& P.H. Winne (Eds.), Handbook of educational psychology ( $2^{\text {nd }}$ ed., pp. 369-389). Mahwah, NJ: Erlbaum.

Andrew, L. (2007). Comparison of teacher educators' instructional methods with the constructivist ideal. The teacher educator, 42: $157-184$.

Ausubel, D. P., Novak, J. D., \& Hanesian, H. (1978). Educational psychology: A cognitive view (2nd ed.). New York, NY: Holt, Rinehart, and Winston.

Azhar, A. (2017). Sains Dalam Kerangka Islam: Perspektif Amalan Saintis Muslim Silam. Jurnal Hadhari 9, 92, 321-335. Retrieved from http://journalarticle.ukm.my/11347/1/2179962722-1-SM.pdf

Eggen, P. D., \& Kauchak, D. P. (2016). Educational Psychology Windows on Classrooms $\left(10^{\text {th }}\right.$ ed.). England: Pearson Education Limited.

Emmer, E. T., \& Evertson, C. M. (2013). Classroom Management for middle and highschool teachers ( $9^{\text {th }}$ ed.). Boston: Allyn \& Bacon/Pearson.

Esteban-Guitart, M., Serra, J. M., \& Vila, I. (2017). Informationalism and informalization of learnings in 21st century. A qualitative study on meaningful learning experiences. Social and Education History 6(1), 1-25. doi:10.17583/hse.2017.2111

Ghazali, N., \& Nordin, M. S. (2019). Measuring Meaningful Learning Experience: Confirmatory Factor Analysis. International Journal of Innovation, Creativity and Change, 9(12), 283296. 
Ghazali, N., \& Nordin, M. S. (2019). Measuring Meaningful Learning Experience: Confirmatory Factor Analysis. International Journal of Innovation, Creativity and Change, 9(12), 283296.

Ghazali, N., Mustakim, S. S., \& Nordin, M. S. (2020). Development of meaningful learning scale. Journal of Critical Reviews, 7(9), 2107-2117.

Ghazali, N. B., \& Nordin, M. S. (2018). The perception of university lecturers of teaching and learning in massive open online courses (MOOCs). Journal of Personalized Learning, 2(1), 52-57.

Helyer, R. (2015). Learning through Reflection: The Critical Role of Reflection in Work-Based Learning (WBL). Journal of Work-Applied Management, 7(1), 15-27

Howland, J. L., Jonassen, D. H., \& Marra, R. M. (2012). Goal of Technology Integrations: Meaningful Learning. Meaningful Learning with Technology, 1-19.

Jonassen, D. H., Howland, J., Moore, J., \& Marra, R. M. (2003). Learning to Solve Problems with Technology: A Constructivist Perspective (2nd. Ed). Columbus: Prentice Hall.

Mayer, R. E. (2002). Rote versus meaningful learning. Theory Into Practice, 41(4), 226-232.

Hassan, M. K. (2018). The Necessity of Understanding the Cosmos, Nature and Man, as Well as the Unity of Knowledge, Faith and Ethics from the Worldview of the Qur'an: Implications on an International Islamic University. Revelation and Science, 82, 1-12.

Mohd Yusof Othman. 2020. Kesepadukan IImu Pengetahuan Sains Dalam Sistem Ilmu Wahyu. Journal Of Personalized Learning, 3(1) 2020, 1-13

Norliza Ghazali, Mohamad Sahari Nordin, Arnida Abdullah, \& Ahmad Fauzi Mohd Ayub. (2020). The Relationship between Students' MOOC-efficacy and Meaningful Learning. Asian Journal of University Education, 16(3), 89. https://doi.org/10.24191/ajue.v16i3.11071

Baka, O. R. (2016). Science and Technology for Mankind's Benefit: Islamic Theories and Practices - Past, Present and Future. DIm. Mohammad Hashim Kamali, Osman Bakar, Daud Abdul-Fattah Batchelor, Rugayah Hashim. 2016. Islamic Perspectives on Science and Technology: Selected Conference Papers. Singapore:

Rico, R., \& Ertmer, P. A. (2015). Examining the Role of the Lecturer in Problem-centered Instruction. Tech Trends, 59(4), 96-103

Ruokamo, H., Hakkarainen, P., \& Eriksson, M. (2011). Designing a Model for Enhanced Teaching and Meaningful E-Learning, 375-392. https://doi.org/10.4018/978-1-61350080-4.ch019

Sailin, S. N., \& Mahmor, N. A. (2017). Promoting Meaningful Learning Through Create-ShareCollaborate. Proceedings of the ICECRS, 1(1), 335-340. https://doi.org/10.21070/picecrs.v1i1.502

Sailin, S. N., \& Mahmor, N. A. (2018). Improving student teachers' digital pedagogy through meaningful learning activities. Malaysian Journal of Learning and Instruction, 15(2), 143-173. https://doi.org/10.32890/mjli2018.15.2.6

Sonmez, A., Goçmez, L., Uygun, D., \& Ataizi, M. (2018). A Review of Current Studies of Mobile Learning. Journal of Educational Technology \& Online Learning, 1(1), 13-27.

Vallori, A. B. (2014). Meaningful Learning in Practice. Journal of Education and Human Development, 3(4), 199-209. https://doi.org/10.15640/jehd.v3n4a18

Wan Mohd nor Wan Daud. 2019. Budaya Ilmu Makna dan Manifestasi dalam Sejarah dan Masa Kini. Kuala Lumpur. CASIS \& HAKIM 
Wong, K. P., \& Kong, H. (2015). Facilitating a meaningful learning experience for students by multimedia teaching approach. Asia Pacific Journal of Contemporary Education and Communication Technology, 1(1), 72-80

Zimmerman, B. J. (2000). Self-efficacy: An essential motive to learn. Contemporary Educational Psychology, 25(1), 82-91. https://doi.org/10.1006/ceps.1999.10166

Zimmerman, B. J. (2008). Investigating Self-Regulation and Motivation: Historical background, Methodological Developments, and Future Prospects. American Educational Research Journal, 45(1), 166-183 